
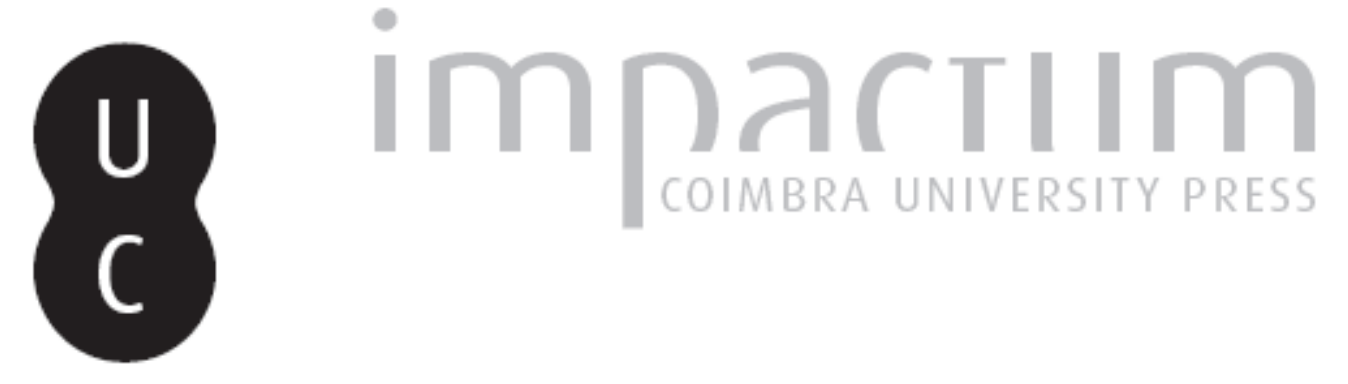

\title{
Património e desenvolvimento em ambiente rural: lugares, rotas e redes
}

\section{Autor(es): $\quad$ Carvalho, Paulo}
Publicado por: Faculdade de Letras da Universidade de Coimbra, Departamento de Geografia

URL

persistente:

URI:http://hdl.handle.net/10316.2/30185

DOI:

DOI:http://dx.doi.org/10.14195/0871-1623_31_1

Accessed : $\quad$ 26-Apr-2023 11:03:52

A navegação consulta e descarregamento dos títulos inseridos nas Bibliotecas Digitais UC Digitalis, UC Pombalina e UC Impactum, pressupõem a aceitação plena e sem reservas dos Termos e Condições de Uso destas Bibliotecas Digitais, disponíveis em https://digitalis.uc.pt/pt-pt/termos.

Conforme exposto nos referidos Termos e Condições de Uso, o descarregamento de títulos de acesso restrito requer uma licença válida de autorização devendo o utilizador aceder ao(s) documento(s) a partir de um endereço de IP da instituição detentora da supramencionada licença.

Ao utilizador é apenas permitido o descarregamento para uso pessoal, pelo que o emprego do(s) título(s) descarregado(s) para outro fim, designadamente comercial, carece de autorização do respetivo autor ou editor da obra.

Na medida em que todas as obras da UC Digitalis se encontram protegidas pelo Código do Direito de Autor e Direitos Conexos e demais legislação aplicável, toda a cópia, parcial ou total, deste documento, nos casos em que é legalmente admitida, deverá conter ou fazer-se acompanhar por este aviso.

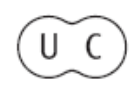




\section{Património e desenvolvimento em ambiente rural: lugares, rotas e redes*}

\section{Paulo Carvalho}

Departamento de Geografia e Centro de Estudos de Geografia e Ordenamento do Território (CEGOT). Faculdade de Letras da Universidade de Coimbra. paulo.carvalho@fl.uc.pt

\section{Resumo:}

As tendências evolutivas do património, tendo como matriz de leitura os principais documentos orientadores e normativos nacionais e internacionais, designadamente a valorização dos contextos rurais e vernaculares e as novas formas e escalas de relação territorial, são acompanhadas de instrumentos para a diversificação, revitalização e requalificação rural, que por sua vez estão na base de importantes iniciativas de salvaguarda e valorização do património rural (ou em contexto rural) com crescente vinculação ao lazer e ao turismo, entre diversos exemplos com lugares, rotas e redes.

Palavras-chave: Património Rural. Desenvolvimento Rural. Lugares. Rotas. Redes.

\section{Resumé:}

Patrimoine et développement rural: lieux, itinéraires et réseaux

Les tendances évolutives du patrimoine, après avoir lu le tableau guidant les documents clé et nationaux et internationaux réglementaires, à savoir l'amélioration de rural vernaculaire et contextes et de nouvelles formes et échelles de relation territoriale, sont accompagnées d'instruments pour la diversification rurale, la revitalisation et la réhabilitation, qui à son tour reposent sur des initiatives importantes pour la sauvegarde et la valorisation du patrimoine rural (ou dans un contexte rural) de plus en plus les reliant à des loisirs et du tourisme, parmi plusieurs exemples de lieux, de routes et de réseaux.

Mots-clés: Patrimoine Rural. Développement Rural. Lieux. Itinéraires. Réseaux.

\section{Abstract:}

Heritage and rural development: places, routes and networks

Evolutionary trends heritage having read the array key guiding documents and national and international regulatory, namely the enhancement of rural vernacular and the contexts and new forms and scales of territorial relationship, are accompanied by instruments for rural diversification, revitalization and rehabilitation, which in turn are based on important initiatives to safeguard and upgrading of the rural heritage (or in a rural context) with growing linking to leisure and tourism among several examples with places, routes and networks.

Keywords: Rural Heritage. Rural Development. Places. Routes. Networks.

* O presente texto resulta da nossa intervenção no âmbito do Workshop "Desenvolvimento Rural Património", organizado pela Secretaria Regional do Ambiente e dos Recursos Naturais/Parque Natural da Madeira, que decorreu em Santana, a 30 de junho de 2011. 


\section{Introdução}

O património, conceito marcado por um certo nomadismo científico e por uma acentuada plasticidade temporal e espacial (em que os seus elementos configuram escalas, tipologias e contextos diversos), emerge como temática de grande visibilidade e relevância estratégica no âmbito do desenvolvimento dos territórios e das populações, em ambientes geográficos de geometria variável, e sob diferentes pretextos: requalificação e revitalização territorial, melhoria das condições e da qualidade de vida das populações, reconstrução de memórias e identidades, processos de mediação educativa (educação patrimonial), e integração dos lugares na esfera dos lazeres turísticos, entre os mais significativos.

Na ótica dos principais documentos orientadores e normativos internacionais, entre convenções, recomendações, resoluções e restantes atos, as tendências evolutivas do património permitem sublinhar o crescimento e alargamento do campo patrimonial, a maior relevância das dimensões imateriais e dos ambientes rurais e vernaculares, a valorização do contexto paisagístico, a aproximação em relação aos cidadãos (incentivar a participação dos cidadãos nas diversas tarefas relacionadas com a proteção e a valorização do património e estabelecer com eles uma nova relação, a responsabilidade crescente do poder local, o incremento das estratégias de cooperação e a construção de redes, o caráter utilitário (no sentido de encontrar/ atribuir função), e ainda o reconhecimento da educação patrimonial.
A integração do património nos processos de desenvolvimento económico, social e cultural dos territórios e das populações, revela uma tipologia ampla e complexa de estratégias/intervenções, que inclui os lazeres turísticos, designadamente o turismo cultural e ecológico, os museus (Figura 1) e os parques temáticos, os eventos culturais (Figura 2), os estatutos de proteção e a classificação de lugares (Figura 3), as operações de requalificação urbanística e ambiental (Figura 4), entre as mais relevantes.

As perspetivas e as intervenções da União Europeia no âmbito do mundo rural refletem a transição de uma conceção agrícola, centrada na agricultura e direcionada para os agricultores e suas organizações, para uma conceção pós-agrícola alicerçada na valorização de novas atividades como suporte essencial da renovação e viabilidade do mundo rural, que por sua vez acompanha o maior interesse dos territórios rurais por parte da população urbana.

Esta última, orientada para o território e para o conjunto da população rural, configura novas oportunidades para salvaguardar, valorizar e fruir o património, como o demonstram diversos programas e iniciativas sobretudo na última década, através de exemplos paradigmáticos entre lugares, rotas e redes.

\section{Património: tendências evolutivas e dimensões pós-modernas}

A inclusão do património na agenda do planeamento e do desenvolvimento territorial é indissociável
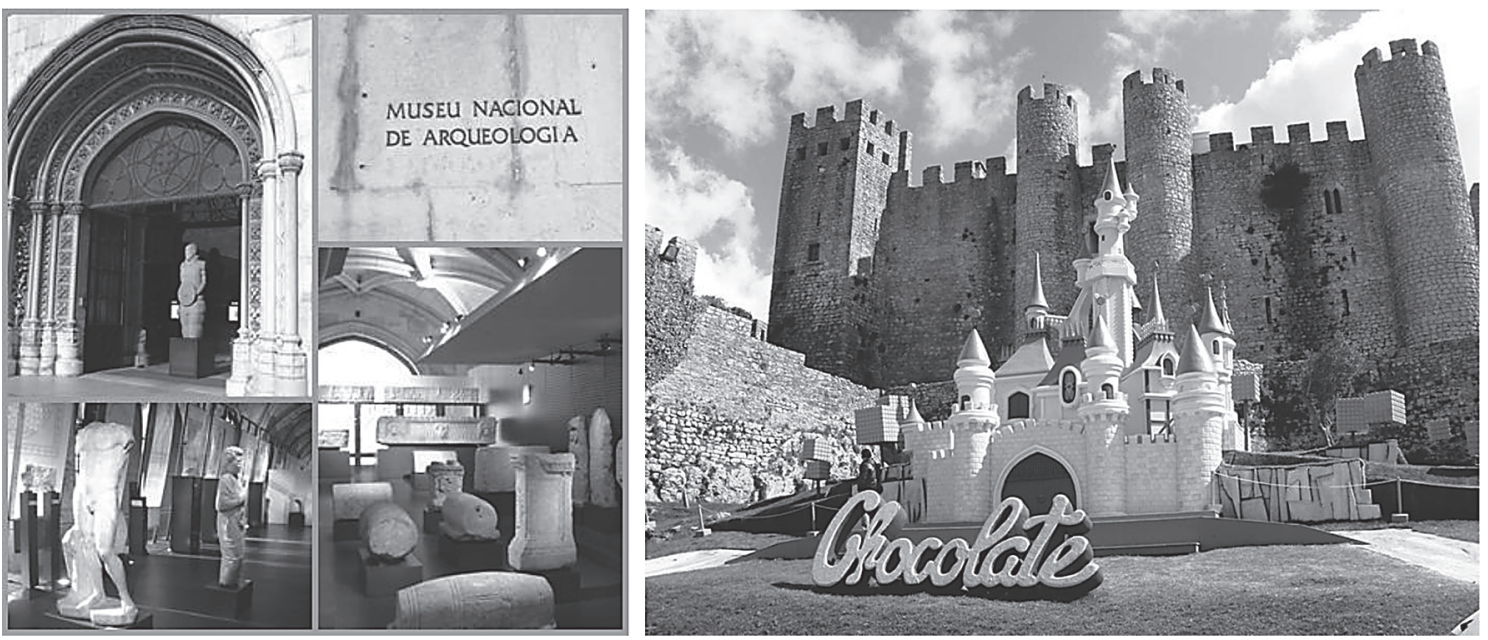

Figuras 1 e 2

Museu Nacional de Arqueologia (Lisboa, segundo composição fotográfica de Juliana Correia, 2011) e Festival do Chocolate (Óbidos, 2012) 

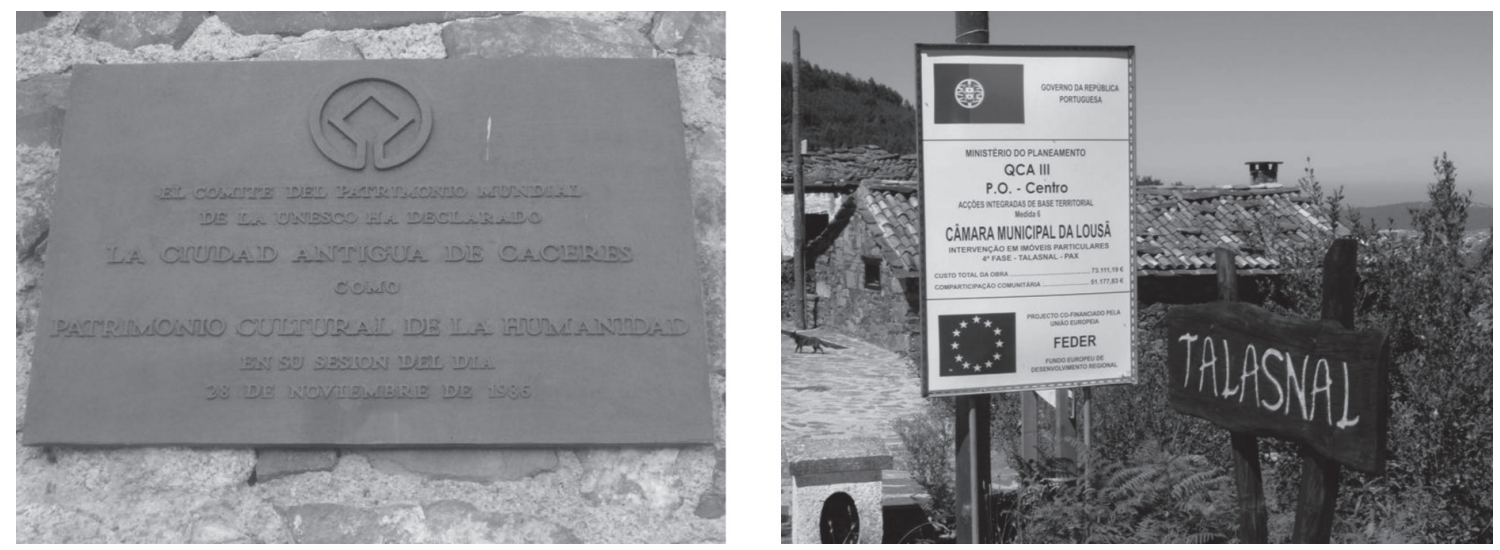

Figuras 3 e 4

Património Cultural da Humanidade (Cáceres, 2008) e intervenção de requalificação urbana no âmbito do Programa das Aldeias do Xisto (Talasnal, 2008)

de um conjunto significativo de documentos orientadores e normativos (relacionados, em particular, com a UNESCO e o Conselho da Europa) que ilustram as preocupações contemporâneas no âmbito da sua proteção e valorização. A terminologia hoje utilizada reflete o alargamento e a diversidade dos bens a patrimonializar, onde se incluem as dimensões intangíveis (música, festividades, tradições orais, saber-fazer, entre outras Figuras 5 e 6) e os novos desafios como, por exemplo, os conjuntos arquitetónicos rurais (Figura 7) e urbanos (Figura 8), os imóveis e os equipamentos industriais, as arquiteturas de veraneio (Figura 9), as termas, as infraestruturas e os meios de transporte e os aspetos geológicos e naturais (Figura 10).
Em Portugal, de acordo com a Lei n. ${ }^{\circ}$ 107/2001 (que estabelece as bases da política e do regime de proteção e valorização do património cultural), o conhecimento, estudo, salvaguarda, valorização e divulgação do património cultural "visam incentivar e assegurar o acesso de todos à fruição cultural; vivificar a identidade comum da Nação Portuguesa e das comunidades regionais e locais a ela pertencentes (...); promover o aumento do bem-estar social e económico e o desenvolvimento regional e local; defender a qualidade ambiental e paisagística”.

As preocupações em matéria de património cultural aparecem alinhadas com as grandes tendências internacionais e os compromissos assumidos pelo país
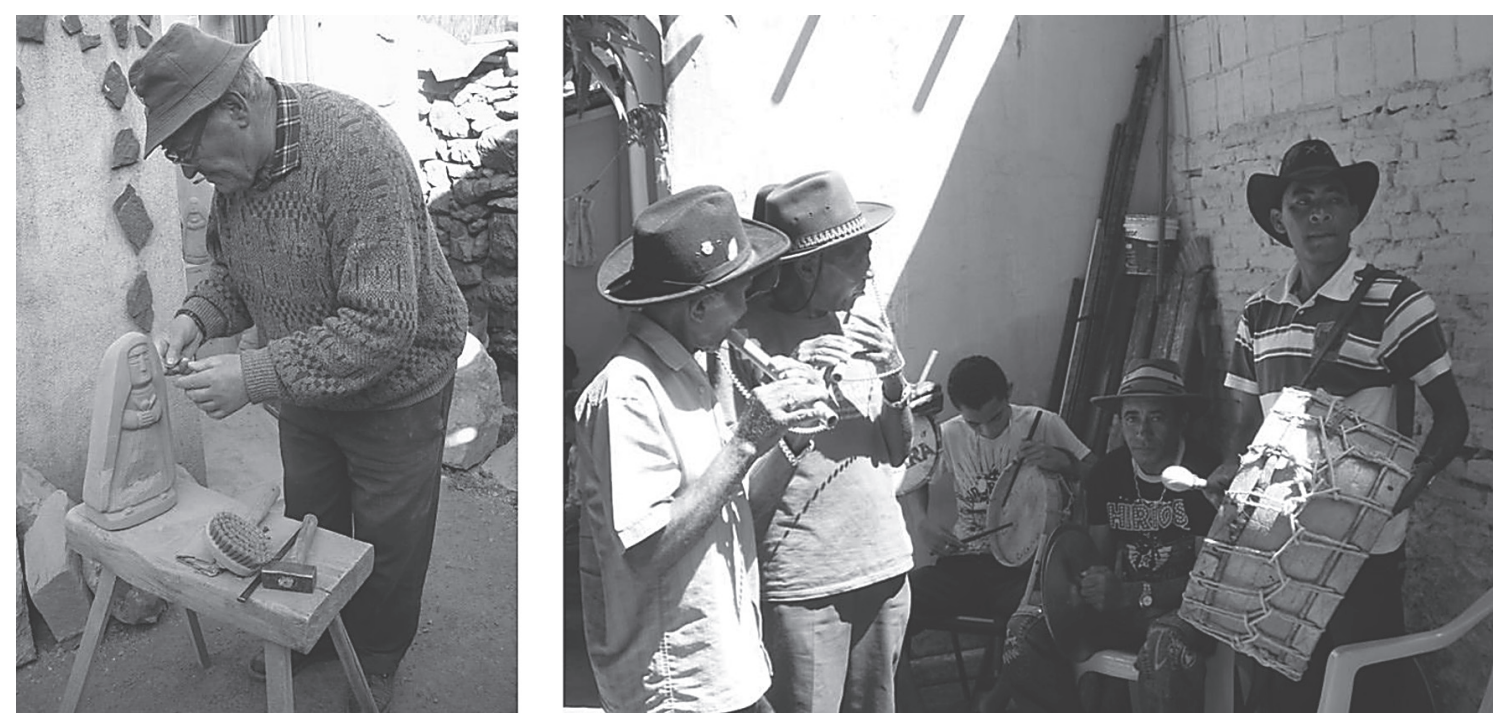

Figuras 5 e 6

Escultor Carlos Rodrigues (Gondramaz, 2004) e banda cabaçal dos Irmãos Aniceto (Crato, Ceará/Brasil, 2012) 

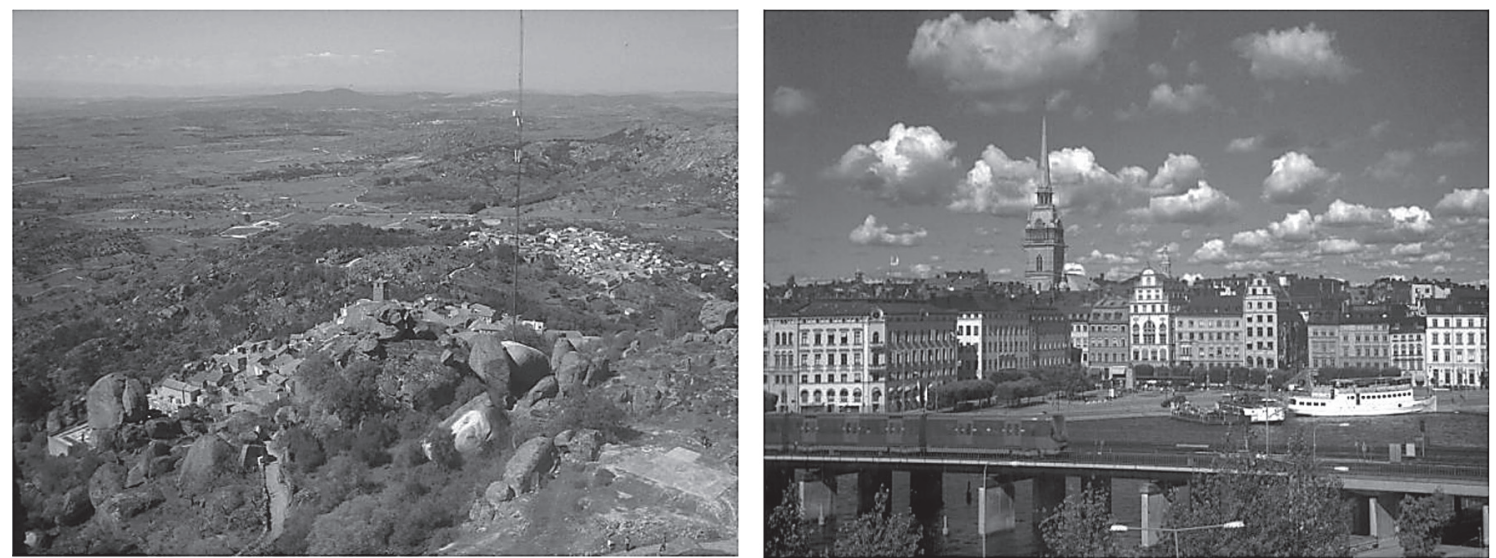

Figuras 7 e 8

Monsanto (Aldeia Histórica, 2004) e Estocolmo (Centro Histórico, 2001)
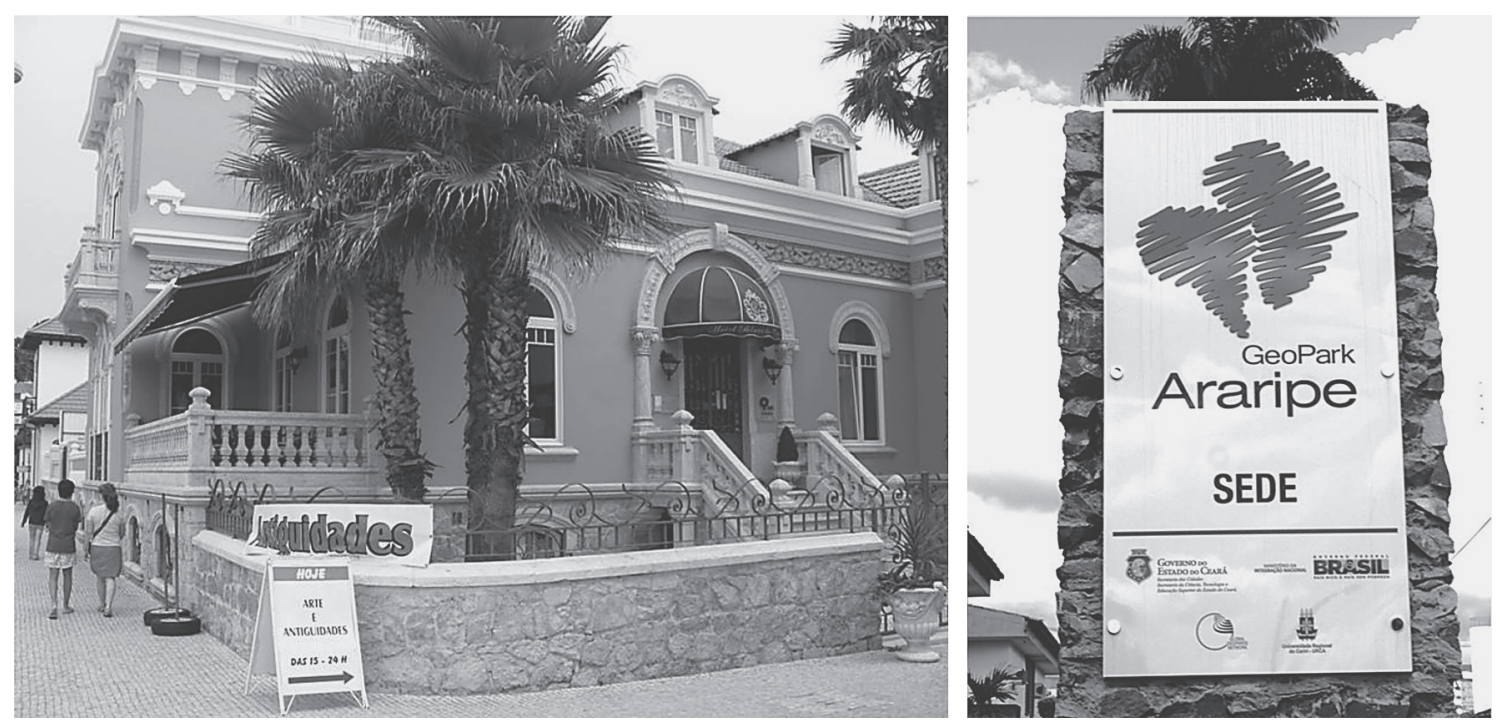

Figuras 9 e 10

Casa de veraneio convertida em Hotel de Charme e Casa de Chá (São Martinho do Porto, 2011) e Geoparque Araripe (Ceará/Brasil, 2012)

nesta matéria, designadamente: a valorização do enquadramento paisagístico (o quadro relacional influencia de forma estática ou dinâmica o modo como ele é percebido); a definição de áreas de proteção; a elaboração de um plano de pormenor e de salvaguarda para os novos imóveis classificados; a valorização da participação pública dos cidadãos; a atribuição de responsabilidade crescente aos municípios, que podem e devem desempenhar um papel relevante, especialmente no âmbito dos planos municipais de ordenamento do território.

No contexto da gestão territorial, segundo a Lei de Bases da Política de Ordenamento do Território e de Urbanismo (Lei $n^{\circ} 48 / 98$, de 11 de agosto, com as alterações introduzidas pela Lei $n^{\circ}$ 54/2007, de 31 de agosto), a salvaguarda e a valorização do património cultural decorre, no essencial, quer dos instrumentos de desenvolvimento territorial, quer dos instrumentos de planeamento territorial. Os primeiros, no âmbito de diretrizes de natureza estratégica, revelam-se através de políticas e ações sectoriais, como o Programa Operacional da Cultura (Figura 11), e de forma indireta ou complementar por via de diversos programas de desenvolvimento como, por exemplo, os Programas Operacionais Regionais (Figura 12), o LEADER (desenvolvimento rural), o POLIS (requalificação urbana) e o INTERREG (desenvolvimento transfronteiriço). Os segundos, no contexto de orientações de natu- 

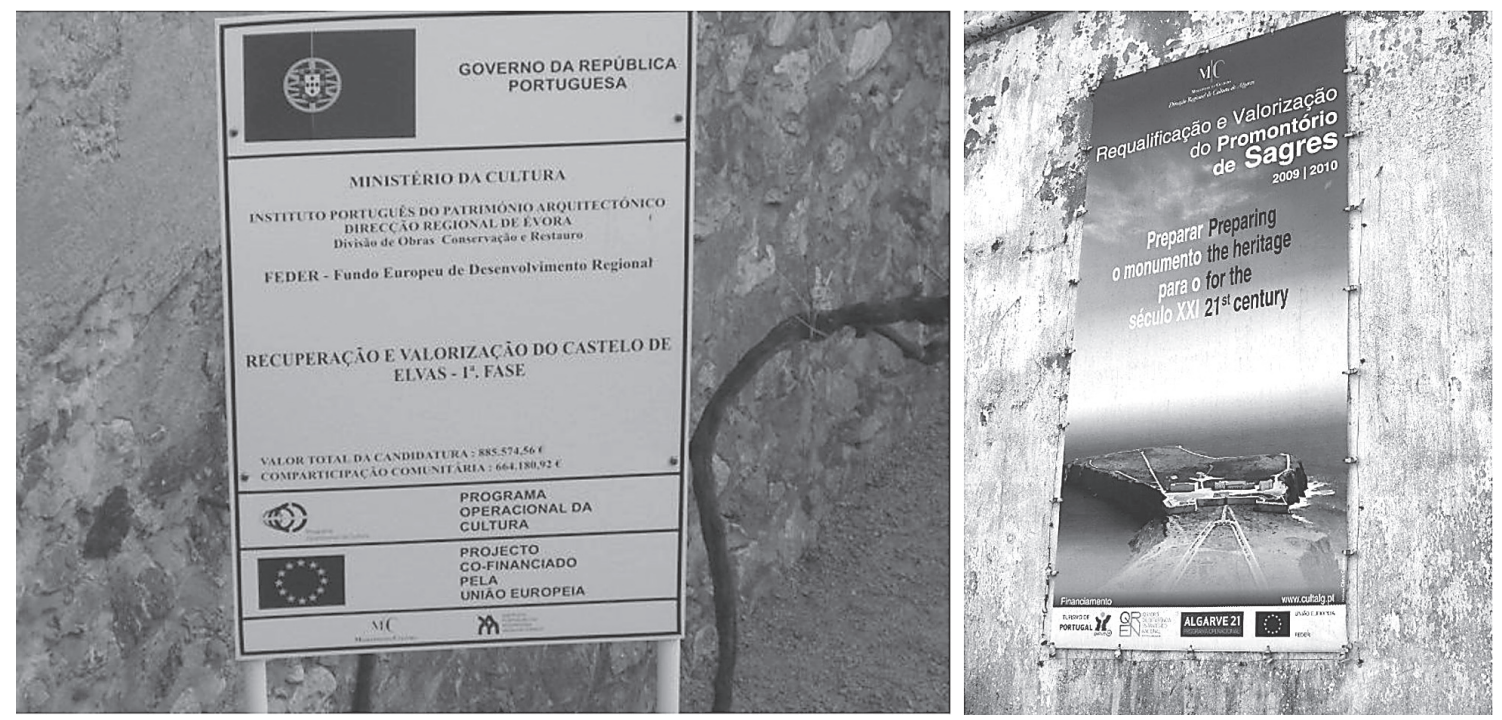

Figuras 11 e 12

Intervenções em património construído suportadas em programas nacionais e fundos comunitários: Elvas (2000-2006) e Promontório de Sagres (2007-2013)

reza regulamentar, incidem sobretudo em matérias relacionadas com a regulação do uso do solo e têm como matriz de maior visibilidade os Planos Municipais de Ordenamento do Território (PMOT), em articulação com os demais instrumentos de gestão territorial relevantes.

De acordo com o Decreto-Lei n. ${ }^{\circ} 380 / 99$, de 22 de setembro, que estabelece o regime jurídico dos instrumentos de gestão territorial, o património arquitetónico e arqueológico é reconhecido com um recurso territorial. 0 mesmo diploma determina que as medidas indispensáveis à proteção e valorização deste património (definido como "os elementos e conjuntos construídos que representam testemunhos da história da ocupação e do uso do território e assumem interesse relevante para a memória e identidade das comunidades") decorram do programa nacional da política de ordenamento do território, dos planos regionais, dos planos intermunicipais de ordenamento do território, e dos planos sectoriais relevantes, tendo em vista acautelar o uso dos espaços envolventes, e reserva aos PMOT o estabelecimento dos parâmetros urbanísticos aplicáveis e a delimitação de áreas de proteção.

O Decreto-Lei n. ${ }^{\circ}$ 309/2009, de 23 de outubro, reconheceu que é "tarefa fundamental do Estado proteger e valorizar o património cultural como instrumento primacial de realização de dignidade da pessoa humana, objeto de direitos fundamentais, meio ao serviço da democratização da cultura e esteio da independên- cia e identidades nacionais", e, ainda mais relevante, contribuiu para definir o procedimento de classificações de bens culturais imóveis, o regime das zonas de proteção e o estabelecimento das regras para a elaboração do plano de pormenor de salvaguarda. Este "estabelece as orientações estratégicas de atuação e as regras de uso e ocupação do solo e edifícios necessárias à preservação e valorização do património cultural existente na sua área de intervenção, desenvolvendo as restrições e os efeitos estabelecidos pela classificação do bem imóvel e pela zona especial de proteção" (Decreto-Lei n. ${ }^{\circ}$ 309/2009).

A proteção e valorização do património construído na esfera de ação dos PMOT envolve a identificação (obrigatória) dos bens classificados (no contexto das "servidões e restrições de utilidade pública em vigor que possam constituir limitações ou impedimentos a qualquer forma específica de aproveitamento") e também pode incluir a identificação de espaços de elevado valor patrimonial para os quais são definidos regulamentos especiais de gestão urbanística, tudo justificado e apoiado nos estudos de caracterização do território municipal e nos relatórios que explicitam os objetivos estratégicos/opções do plano e a respetiva fundamentação técnica (suportada na avaliação das condições económicas, sociais, culturais e ambientais para a sua execução). Considerando, de igual modo, as dificuldades dos municípios em definir o programa de execução das intervenções previstas e respetivo plano de financiamento, é fácil concluir que os PMOT, através 
de uma conceção e prática redutora em matéria de património cultural, são mais instrumentos de catalogação de bens imóveis classificados do que ferramentas de uma estratégia de ação tendo em vista valorizar o referido património.

\section{Rural pós-produtivista: caminhos e sentidos de pluralidade}

As orientações estratégicas e as políticas da União Europeia para o mundo rural revelam duas tendências principais: da génese da política agrícola comum até meados dos anos 80 , é evidente a preponderância da agricultura e a primazia das orientações produtivistas; desde então, mas sobretudo na última década, emerge e consolida-se uma nova perspetiva, na atmosfera de diversificação da base económica e de integração das políticas, ancorada ao desenvolvimento rural (CARVALHo, 2009).

As perspetivas e as intervenções da União Europeia no âmbito do mundo rural refletem a transição de uma conceção agrícola, centrada na agricultura e direcionada para os agricultores e suas organizações, que coincide com um período de acentuado enfraquecimento e desvitalização económica, social e demográfica de uma parte significativa do mundo rural, para uma conceção pós-agrícola alicerçada na valorização de novas atividades como suporte essencial da renovação e viabilidade do mundo rural, que por sua vez acompanha o maior interesse dos territórios rurais por parte da população urbana. Esta última, de cariz territorial, norteada para o território e para o conjunto da população rural, considera que a política agrícola deve ser integrada no quadro de uma política de desenvolvimento rural que impulsione a diversificação de atividades e dote os territórios rurais de infraestruturas e equipamentos suficientes para que a população se mantenha nos espaços rurais em condições de qualidade (Moyano Estrada, 2006) e responda às exigências da sociedade do lazer.

A tentativa de diversificar a base económica do mundo rural, e a sua inclusão nas novas escolhas geográficas de fenómenos como o lazer e o turismo, não pode ser dissociada das mudanças económicas, sociais e culturais ocorridas no espaço urbano. RIBEIRO (2003), citada por CARVALHo (2005: 167-168), assinala fatores como os "níveis crescentes de instrução da população, o aumento dos tempos livres e as novas tendências de gestão e usufruto dos mesmos - férias repartidas -, a melhoria das infraestruturas de acesso e das comunica- ções, e refere um movimento de revalorização do mundo rural, na génese da tentativa de encontrar contrapontos, antídotos e compensações, face à crescente artificialidade, insegurança, estandardização, impessoalidade, saturação, dos modos e contextos de vida urbanos".

Reconhecendo a importância estratégica do mundo rural e a sua crescente complexidade e diversidade (relacionada com o alargamento da União Europeia), as novas políticas têm como eixos estruturantes o reconhecimento da especificidade dos territórios e do seu potencial de recursos, e a prioridade atribuída aos conceitos de sustentabilidade, subsidiariedade e parceria. O objetivo principal é conciliar a prática agrícola com as preocupações ambientais e paisagísticas, preservar e valorizar a paisagem e a diversidade do património cultural, e ao mesmo tempo encontrar novas funções/usos para os territórios rurais compatíveis com esses princípios orientadores (CARVALHO, 2006).

Ao mesmo tempo, as recentes orientações europeias em matéria de desenvolvimento do mundo rural, com a transição de um modelo orientado para o setor agrícola (com objetivos produtivistas alicerçados nos mercados, preços e excedentes, entre outros) em direção a um modelo centrado na sociedade rural e na modelação das suas paisagens, são acompanhadas de uma valorização crescente da participação dos atores rurais na definição e gestão das políticas.

O Programa de Iniciativa Comunitária LEADER (Ligação Entre as Ações de Desenvolvimento da Economia Rural), pelo seu caráter inovador, configura uma referência incontornável e, ainda hoje, representa a dimensão de maior visibilidade desta nova conceção de desenvolvimento para o mundo rural europeu.

O LEADER constitui uma abordagem inovadora e pioneira neste domínio e configura uma ferramenta chave da política de desenvolvimento do mundo rural a partir de uma metodologia ascendente e de um conjunto de intervenções (com uma componente territorial muito marcada) (Plaza Gutí́rRez, 2006). O Programa, lançado pela Comissão Europeia, em 1991, apresenta como traços inovadores a programação e gestão do território ("zonas de intervenção" que correspondem a uma escala sub-regional - Figura 13) mediante parcerias envolvendo diversos agentes de desenvolvimento local, como autarquias, associações culturais e sociais, associações profissionais ou sectoriais, empresas, ou mesmo privados a título individual, embora com enquadramento regulamentar e cofinanciamento público comunitário e nacional (CARVALHo, 2005). 


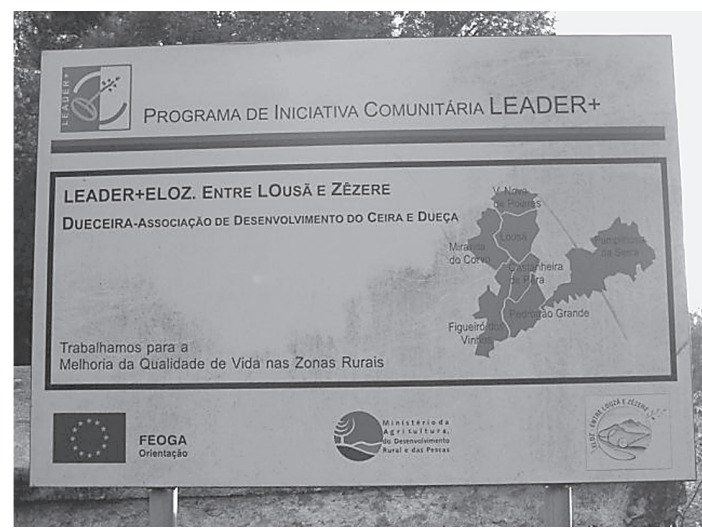

Figura 13

Identificação da área territorial ELOZ (Entre Lousã e Zêzere) no contexto da intervenção do PIC LEADER+ (2000-2006)

Em três fases de execução, no alinhamento da programação e implementação das políticas públicas da União Europeia, pretendeu diversificar a economia das áreas rurais mediante a aplicação de programas supramunicipais vertebrados em torno da melhoria da qualidade de vida da população, a utilização de novos conhecimentos e tecnologias e a valorização dos recursos naturais e culturais. A cooperação e a constituição de redes entre territórios rurais constituíram também preocupações e eixos orientadores do LEADER (designadamente em 2000-2006).

A aprovação do FEADER (Fundo Europeu Agrícola de Desenvolvimento Rural) e a sua implementação no período de 2007 a 2013, com três eixos temáticos de atuação/objetivos fundamentais (o aumento da competitividade da agricultura e silvicultura; a melhoria do ambiente e da paisagem rural; a promoção da qualidade de vida nas áreas rurais e a diversificação da atividade económica no conjunto dos espaços rurais), veio institucionalizar o desenvolvimento rural como dimensão política integrada e reconhecer, também, a importância da participação dos atores do mundo rural na definição e gestão das políticas e, assim, consolidar a abordagem LEADER que agora passa a ser utilizada como metodologia/ferramenta de trabalho nomeadamente para a implementação da qualidade de vida e a diversificação económica rural, com o objetivo de implementar estratégias locais para o desenvolvimento rural através de parcerias público-privadas a nível local.

No caso de Portugal, os programas de desenvolvimento rural para o Continente (PRODER - Figura 14), a Madeira (PRODERAM) e os Açores (PRORURAL) e ainda o programa da Rede Rural Nacional (com o intuito de reforçar o intercâmbio entre os agentes dos territórios rurais) são a expressão mais visível para a prossecução dos referidos objetivos.

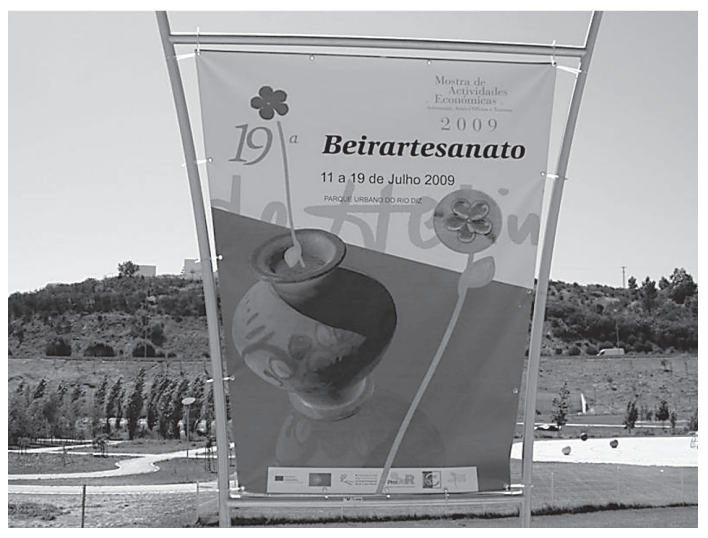

Figura 14

Iniciativa Beirartesanato (Guarda, 2009), com o apoio do PRODER

Portanto, a política europeia de desenvolvimento para os espaços rurais reconhece a especificidade dos territórios e do seu potencial de recursos, e reflete orientações e objetivos diferenciados, através de medidas de apoio direcionadas para os setores agrícola e florestal (tendo presente as preocupações de competitividade e eficiência produtiva, e as exigências ambientais), para a diversificação da base económica e para a revitalização social.

A aplicação desta política diferenciada nas suas iniciativas e destinatários deverá sedimentar uma ruralidade com mais dignidade e qualidade de vida, e contribuir para salvaguardar e valorizar os recursos estratégicos do mundo rural, como é o caso do património cultural.

\section{Escalas de intervenção e exemplos/cenários de resgate e fruição do património cultural em ambiente rural: lugares, rotas e redes}

O património rural emerge como preocupação crescente na normativa internacional sobre salvaguarda e valorização patrimonial, configura tipologias, escalas e contextos muito diversos, e constitui um recurso de grande relevância para os novos caminhos do desenvolvimento endógeno.

O interesse cultural relevante do mundo rural, de acordo com valores de "memória, antiguidade, autenticidade, originalidade, raridade, singularidade ou exemplaridade", e a sua inclusão no património, reflete bens materiais (imóveis e móveis) e imateriais, "mas tam- 

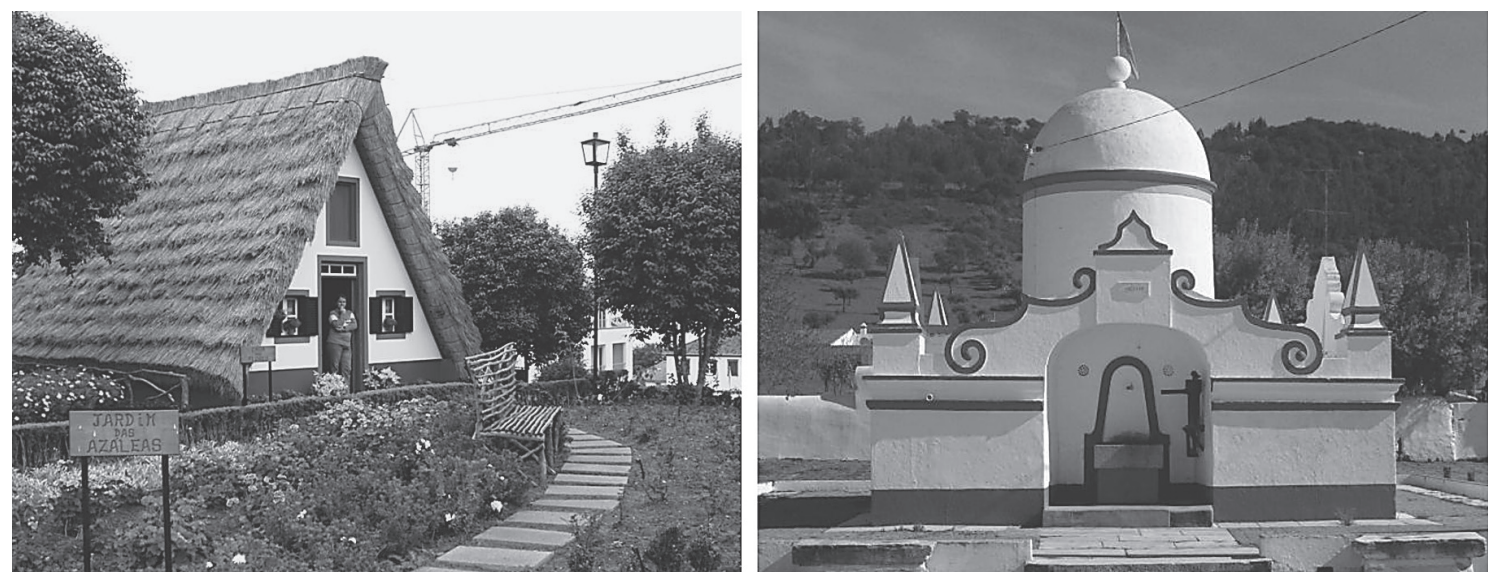

Figuras 15 e 16

Casa típica (réplica) em Santana (Madeira, 2011) e fontenário do Telheiro (Reguengos de Monsaraz/Alentejo, 2003)

bém, quando for caso disso, os respetivos contextos que, pelo seu valor de testemunho, possuam com aqueles uma relação interpretativa e informativa" (Lei n. ${ }^{\circ}$ 107/2001).

O património rural material imóvel assume diferentes dimensões ou expressões. Sem a pretensão de ser exaustivo, importa referir as estruturas edificadas de maior simbolismo e expressão patrimonial, entre edifícios de natureza militar (atalaias, castelos, muralhas e fortificações), religiosa (mosteiros e conventos), e civil (palácios, palacetes, casas brasonadas e solarengas) de forma individual ou em conjunto; as construções com menor pretensão artística e arquitetónica mas igualmente relevantes (como os imóveis para habitação - Figura 15 -, e pequenas edificações relacionadas com a devoção religiosa); os caminhos antigos de ligação entre lugares, de acesso aos terrenos de cultivo e aos espaços florestais, de circulação do gado; as estruturas de apoio à circulação (terrestre - nas vertentes pedestre, rodoviária e ferroviária; fluvial e marítima) e as suas obras de arte (pontes, pontões, fontenários Figura 16); as igrejas, capelas e ermidas; as estruturas produtivas pré-industriais (fornos de telha e cal, fornos de carvão, engenhos - papel e açucar -, moinhos, azenhas, lagares); as gramáticas de pedra (muros, socalcos, curraletas - Figura 17); os sistemas de irrigação e de adução de água (poços, noras, engenhos, levadas, aquedutos e fontenários); os imóveis de serviços públicos (de habitação como as casas da guarda florestal e dos cantoneiros, e de apoio como os anexos das casas florestais e os depósitos de ferramentas da junta autónoma de estradas); as construções relacionadas com as atividades agrícolas, pecuárias e florestais tradicionais (palheiros, celeiros, adegas, espigueiros, eiras, pom- bais, abrigos de pastores). Em sentido mais global, a paisagem, quando construída pelas populações rurais e capaz de manifestar uma relação harmoniosa e equilibrada com o suporte físico, assumindo uma evidente dimensão cultural, é também uma forma incontornável de património material (as paisagens vinhateiras do Alto Douro e da Itha do Pico, em Portugal, reconhecidas como de valor universal pela UNESCO, são dois exemplos paradigmáticos deste conceito).

De igual modo, é necessário considerar as estruturas e os equipamentos relacionados com as atividades de pendor industrial, como, por exemplo, a lavra ativa em minas (ferro, volfrâmio, ouro, cobre), a tecelagem e a fiação, a fileira da cortiça e do papel, e ainda os edifícios ligados a figuras de relevo na vida local ou nacional, em áreas como a política, a ciência, as artes (pintura - Figura 18 -, escultura, música) e as letras, e também aqueles que albergaram serviços e funções públicas como, por exemplo, escolas, igrejas (capelas e ermidas), casas que serviram de sede do poder (político e judicial).

Os bens culturais móveis suscetíveis de integrar o património cultural repartem-se por "espécies artísticas, etnográficas, científicas e técnicas, bem como espécies arqueológicas, arquivísticas, áudio-visuais, bibliográficas, fotográficas, fonográficas". As formas de expressão no mundo rural incluem, para além dos sítios de interesse arqueológico, os objetos do quotidiano, do espaço de produção (ferramentas, utensílios e alfaias agrícolas) ao espaço de vida familiar (vestuário, mobiliário, peças utilitárias de barro, esmalte, louça e vidro), e ainda os utensílios de atividades em contexto rural, desde os estabelecimentos de comércio e "serviços"), aos espaços pré-industriais e industriais. 

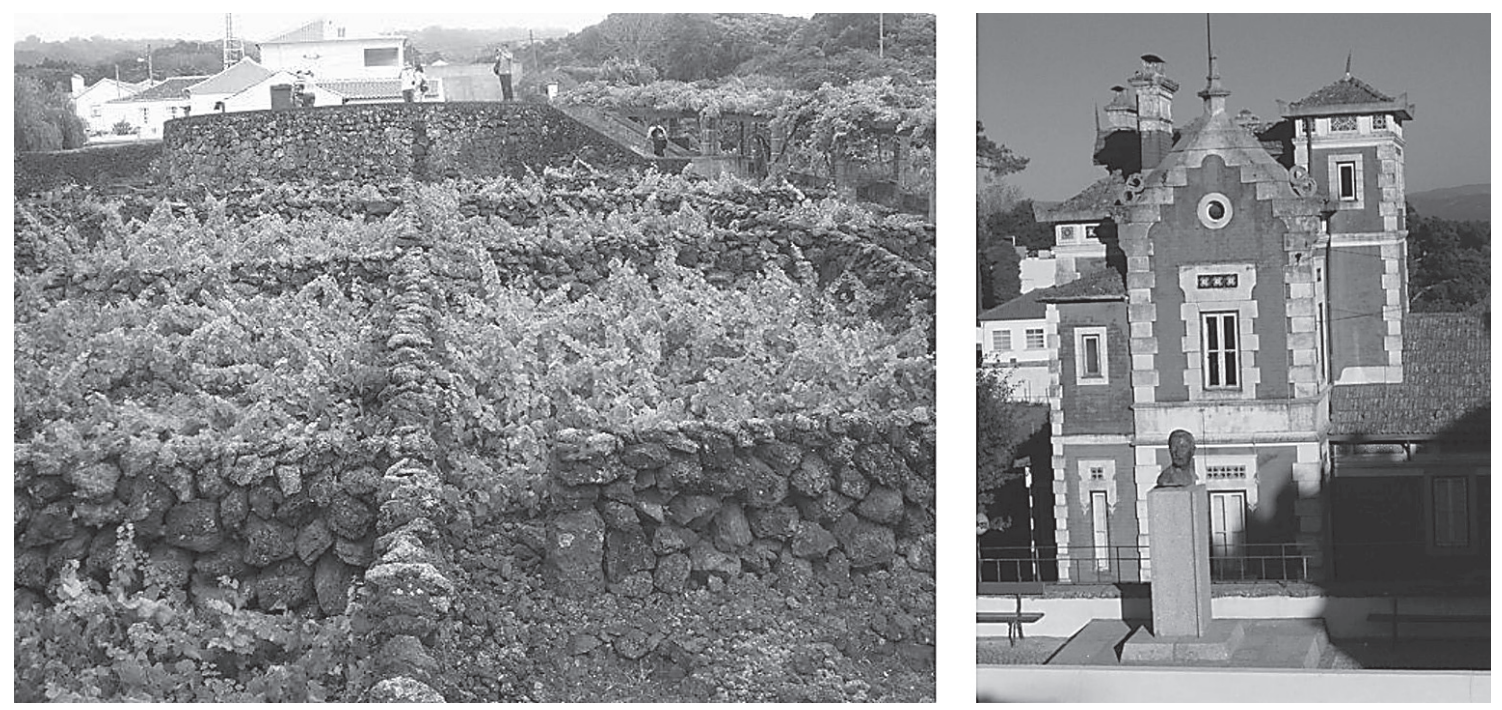

Figuras 17 e 18

Curraletas (produção de vinho nos Biscoitos/Ilha Terceira, 2008) e Casulo Malhoa - casa-atelier do Mestre José Malhoa (Figueiró dos Vinhos, 2004)

Os bens imateriais configuram "realidades que, tendo ou não suporte em coisas móveis ou imóveis, representam testemunhos etnográficos ou antropológicos com valor de civilização ou de cultura com significado para a identidade e memória coletivas". Estão neste caso, as "expressões orais de transmissão cultural e os modos tradicionais de fazer, nomeadamente as técnicas tradicionais de construção e de fabrico e os modos de preparar os alimentos" (Lei n. ${ }^{\circ}$ 107/2001), entre outros. No mundo rural, destacam-se as técnicas e os saberesfazer no âmbito de atividades como a agricultura, a criação de gado/pecuária, a silvicultura, o artesanato e outras artes e ofícios tradicionais; as músicas e as festividades; os momentos mais marcantes do ciclo etnográfico (matança do porco, descamisada, apanha e moagem da azeitona), as tradições orais, entre outras. A gastronomia merece também destaque neste domínio, com o reconhecimento de produtos tradicionais genuínos e singulares, através de medidas normativas orientadas para a sua valorização (por exemplo, os estatutos de denominação de origem protegida e denominação de origem controlada), e de formas voluntárias de organização/ associação tendo em vista defender e promover esses produtos, como é o caso das confrarias.

São diversos os fatores de mudança da paisagem e do mundo rural. A urbanização, as acessibilidades, o despovoamento, o declínio das práticas agrícolas, pastoris e silvícolas, o abandono dos espaços e estruturas produtivas, entre outros, representam processos que, com diferente intensidade, deixam marcas incontornáveis no mundo rural e estão na base de preocupações nomeadamente no que diz respeito ao ordenamento do território. 0 abandono da paisagem rural é um dos maiores fatores de risco para o património.

Importa identificar (georeferenciar), caracterizar, dar a conhecer e reconhecer valor, salvaguardar e valorizar os elementos diferenciadores da paisagem e da vida rural. Socalcos, habitações, anexos, estruturas produtivas, caminhos, produtos endógenos, saber-fazer, entre outros, constituem traços de identidade, laços de afetividade e alicerces de memória entre a sociedade e o território.

A salvaguarda e a valorização destes recursos endógenos, incentivadas no contexto de medidas de apoio diretas e indiretas, revelam variados exemplos, entre lugares, rotas e redes.

No âmbito de intervenções em estruturadas edificadas (bens isolados e conjuntos), para além de imóveis particulares (destinados a habitação permanente, temporária e alojamento turístico, e a outras funções como é o caso da atividade industrial em meio rural), encontram-se também edifícios públicos como, por exemplo, antigas casas florestais, casas de cantoneiros, escolas e estações de caminho de ferro (Figura 19), as quais através de protocolos (de cedência de direitos de utilização) e de alienação têm assumido novas funções/ utilizações, nomeadamente o apoio a atividades de investigação, de lazer turístico (alojamento, restauração e cafetaria, postos de informação turística), e de cariz social (centros de dia) e cultural (sedes de associações). Os antigos pombais, moinhos de vento, de maré e hidráulicos, utilizados para alojamento turístico e resi- 


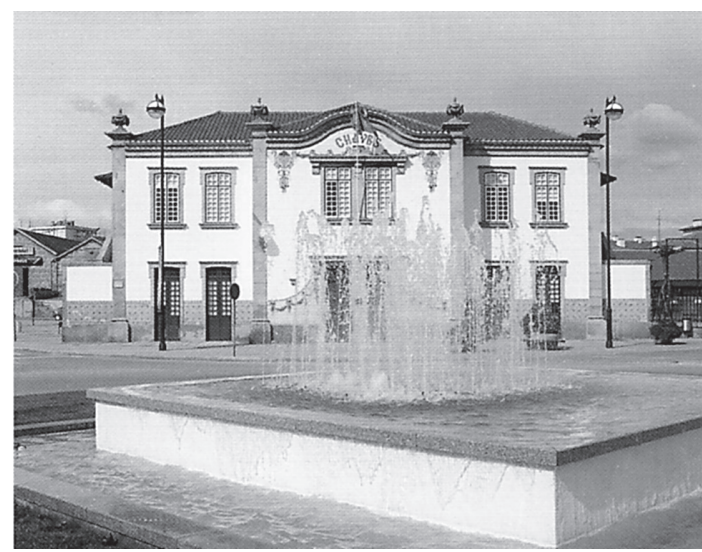

Figura 19

Centro Cultural de Chaves (antiga estação ferroviária) segundo fotografia original de Dario Silva (O Comboio em Portugal, 2006)

dência secundária em diversas regiões do país, depois de recuperados e adaptados, configuram outros exemplos relevantes de iniciativas neste domínio.

Em relação ao património rural móvel, destacamse os projetos e as ações no contexto dos museus. Os exemplos nacionais e internacionais, que podem incluir também bens imóveis, revelam iniciativas centradas na recolha e exposição de peças e testemunhos do passado (paisagem, território e sociedade - Figura 20), de utensílios do quotidiano e das práticas rurais (do trabalho ao lazer - Figura 21), na organização e disponibilização (acesso público) do espólio de figuras relevantes do mundo rural (através das casas-museu), mas de igual modo são evidentes propostas mais ambiciosas, com espaços museológicos abertos, polinucleados, de escala supramunicipal, no sentido de valorizar a paisagem, o património e a participação da população (residentes e

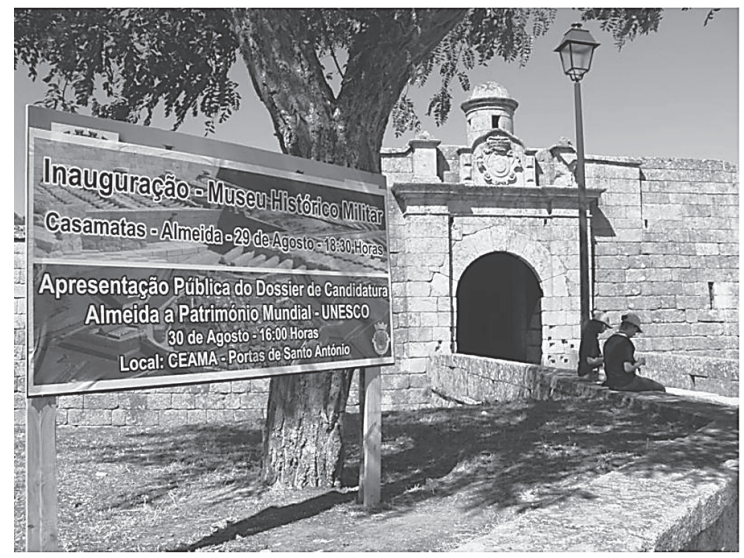

visitantes). A utilização das novas tecnologias de informação e comunicação permite novas soluções de apresentação das coleções e até criar propostas de visita virtual.

A integração do património em cadeias de valor e a necessidade de encontrar escala para viabilizar investimentos em equipamentos e infraestruturas, fazem das rotas, roteiros e redes, opções de interesse e visibilidade crescente em diferentes contextos geográficos.

As rotas decorrem de temáticas com capacidade para construir narrativas sócio-espaciais, induzir organização e fomentar princípios de articulação, cooperação e parceria entre diferentes entidades, e retratam realidades materiais e imateriais do património como, por exemplo, a arte rupestre (Vale do Coa, Ceira - Figura 22, Tejo e Guadiana), o contrabando (Minho, Trás-osMontes, Beira Interior e Alentejo), os vinhos (Douro, Dão, Alentejo, Ribatejo, Oeste), os sabores (Alentejo), o touro e o cavalo (Ribatejo - Figura 23), os judeus (Trancoso e Belmonte), o românico (Vale do Sousa), o imperador Carlos V (Beira Interior Sul), os caminhos de Santiago, a transumância (Serra da Estrela), os escritores do século XX (Região Centro) e os mosteiros Património da Humanidade da Região Centro (Convento de Cristo, Mosteiro de Alcobaça e Mosteiro da Batalha - Figuras 24, 25 e 26).

Em outros casos, como é o exemplo da chanfana (Serra da Lousã), um dos três pratos de carne finalistas no concurso das Sete Maravilhas da Gastronomia Portuguesa (2011), seria relevante utilizar este princípio de estruturação/organização no sentido de encontrar escala e maior visibilidade para as iniciativas de salvaguarda e promoção do património gastronómico regional. Sem anular as iniciativas locais que decorrem das

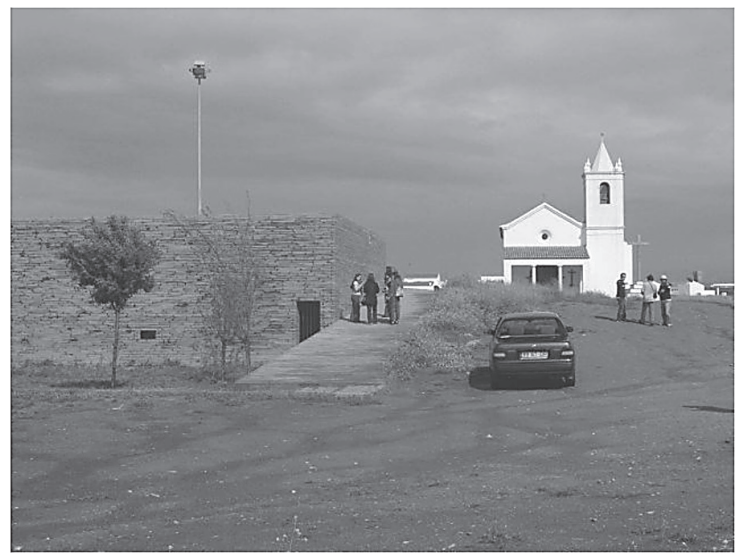

Figuras 20 e 21

Inauguração do Museu Histórico Militar/Casamatas (Almeida, 2009) e Museu da (nova) Aldeia da Luz (Alentejo, 2007) 

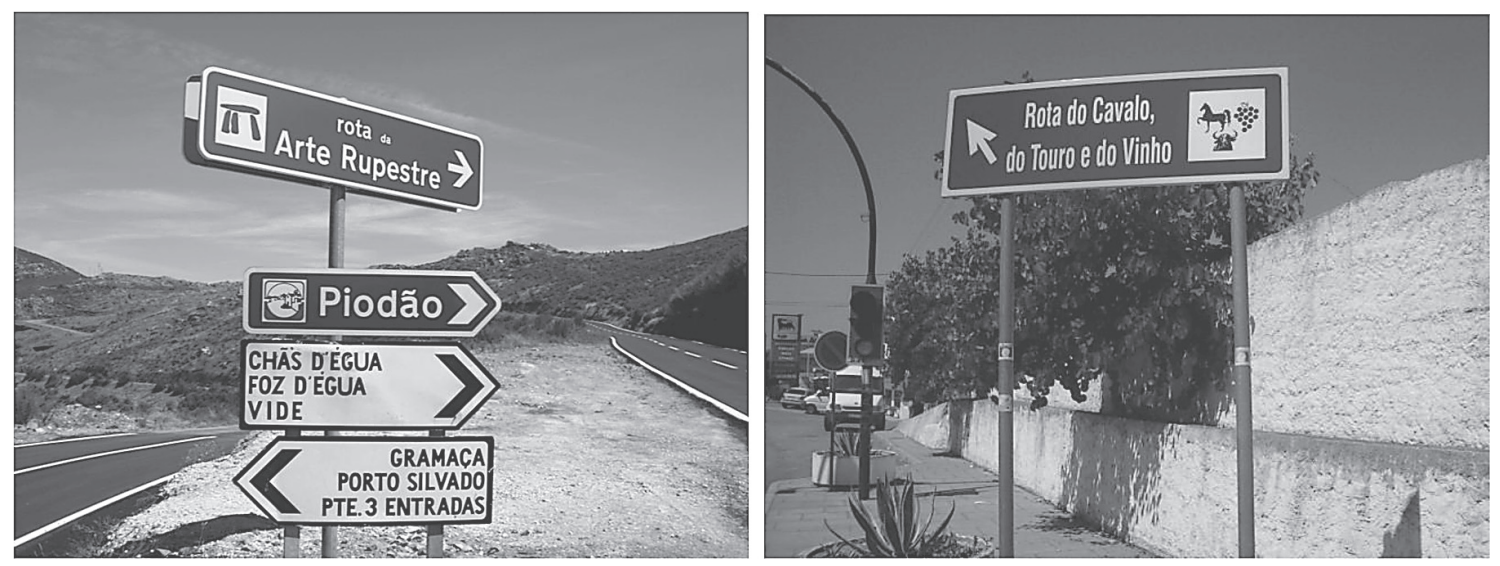

Figuras 22 e 23

Rota da Arte Rupestre (Vale do Ceira, 2009) e Rota do Cavalo, do Touro e do Vinho (Ribatejo, 2008)
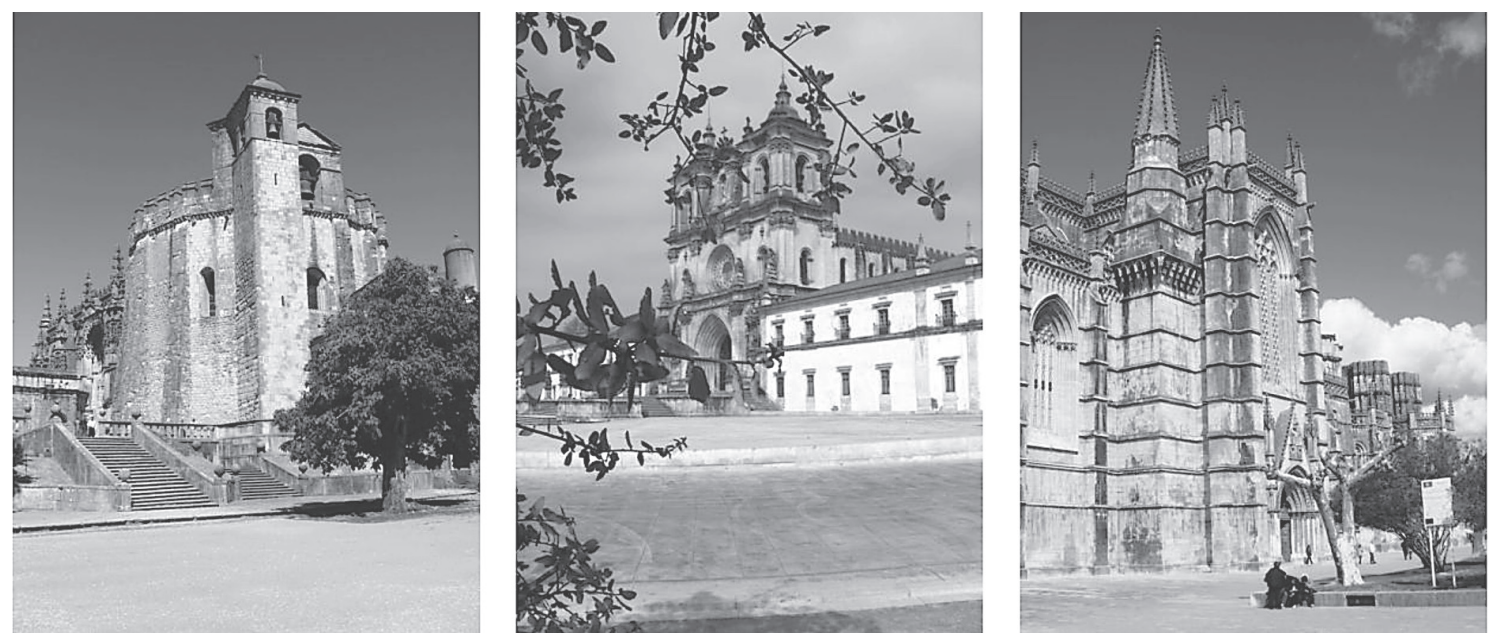

Figuras 24 e 25 e 26

Convento de Cristo, Mosteiro de Alcobaça e Mosteiro da Batalha (2012)

confrarias (com sede em Miranda do Corvo e Vila Nova de Poiares) e de eventos como o Festival do Cabrito (Góis), a Semana do Cabrito (Miranda do Corvo) e o Fim de Semana do Cabrito (Lousã), entre outras, importa conceber e implementar uma rota ou roteiro de escala supramunicipal (que pode ser articulada com alguns equipamentos já existentes designadamente os relacionados com a museologia e a restauração) - também com o intuito de aprofundar o espírito de cooperação que esteve patente na referida candidatura (Figura 27). Os recursos, técnicas e meios vinculados aos saberes-fazer e aos territórios e instituições mais relevantes seriam o fio condutor da rota, com uma entidade gestora (independente) com capacidade operativa nomeadamente ao nível de programação de eventos, coordenação das entidades participantes e a produção e disponibilização de conteúdos (em permanente atualização). O sentido desta proposta seria "Das capitais à rota da Chanfana", com o barro, o vinho, a carne de cabra/cabrito e as respetivas estruturas/equipamentos, espaços e produtores mais representativos, a definir os eixos condutores e os polos de visita (e participação dos visitantes) para esta iniciativa abrangente e inclusiva.

As redes pretendem associar territórios e espaços com afinidades (naturais e/ou culturais), por vezes no contexto de políticas, programas e iniciativas públicas (ou apoiadas pelo Estado), no sentido de atrair investimentos e fixar ativos, de acordo com preocupações de desenvolvimento local e regional, e que podem ter uma gestão comum ou participada. As Aldeias Históricas, as Aldeias do Xisto, as Aldeias Vinhateiras do Douro, as Aldeias de Água (ou Ribeirinhas) de Alqueva, são alguns 


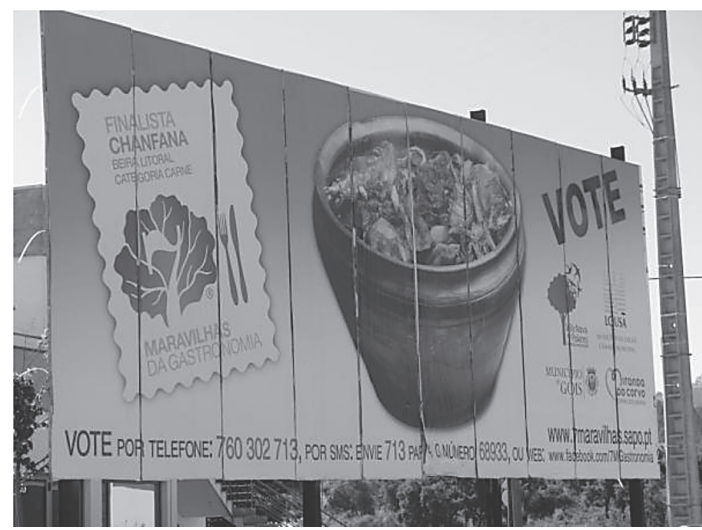

Figuras 27

Outdoor promocional da Chanfana no âmbito das Setes Maravilhas da Gastronomia Portuguesa (EN 17, Poiares, 2011)

exemplos em Portugal desta nova forma de organização (e de génese) de atores (institucionais).

A integração de objetivos económicos, sociais e patrimoniais na estruturação e implementação dos programas de apoio; a criação de novas marcas e produtos turísticos (Figura 28); a produção de conhecimento e a divulgação dos lugares; a articulação, a cooperação e as parcerias entre territórios e agentes; a requalificação de bens, conjuntos e sítios de elevado valor patrimonial; os incentivos orientados para novas atividades económicas vinculadas aos recursos endógenos; a captação de novos residentes e agentes económicos, e a criação de atores institucionais; a melhoria das condições de habitabilidade dos imóveis particulares; as novas possibilidades de utilização e fruição das paisagens, por via de equipamentos e infraestruturas para ativida-

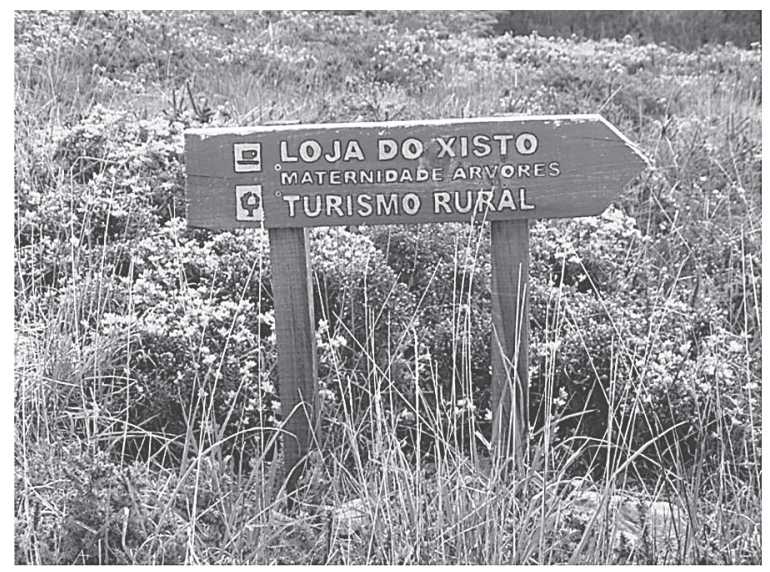

des ao ar livre como as caminhadas (percursos pedestres - Figura 29), o btt, a escalada, o rapel, entre outras, configuram dimensões relevantes no contexto de intervenções (iniciadas em meados dos anos 90) que valorizam as especificidades de territórios e a mobilização e organização dos atores, aqueles que durante um tempo demasiado longo estiveram esquecidos e permaneceram marginais em relação às prioridades de desenvolvimento do país.

Em conclusão, importa sublinhar que a coesão económica, social e territorial de Portugal, mesmo admitindo a fluidez de fronteiras entre as categorias de uso do solo e as novas lógicas de integração dos territórios e de relacionamento dos seus agentes, tem como matriz incontornável a salvaguarda e a valorização do património, como condição fundamental para a melhoria da qualidade estética e vivencial da paisagem.

0 rural, na sua pluralidade de expressões e representações, através do património (natural e cultural), configura uma matriz incontornável daquilo que deve ser a inclusão das paisagens e das populações nos objetivos do desenvolvimento sustentável.

\section{Referências Bibliográficas}

Ashworth, G. e Graham, B. (2005) - Senses of Place: Senses of Time (Col. Heritage, Culture and Identity). Aldershot, Ashgate, pp. 3-12.

BATISTA, F. O. (2006) - "O rural depois da agricultura". In: FonseCA, M. L. (coord) - Desenvolvimento e Território. Espaços Rurais Pós-agrícolas e Novos Lugares de Turismo e Lazer. Lisboa, Centro de Estudos Geográficos, pp. 85-105.

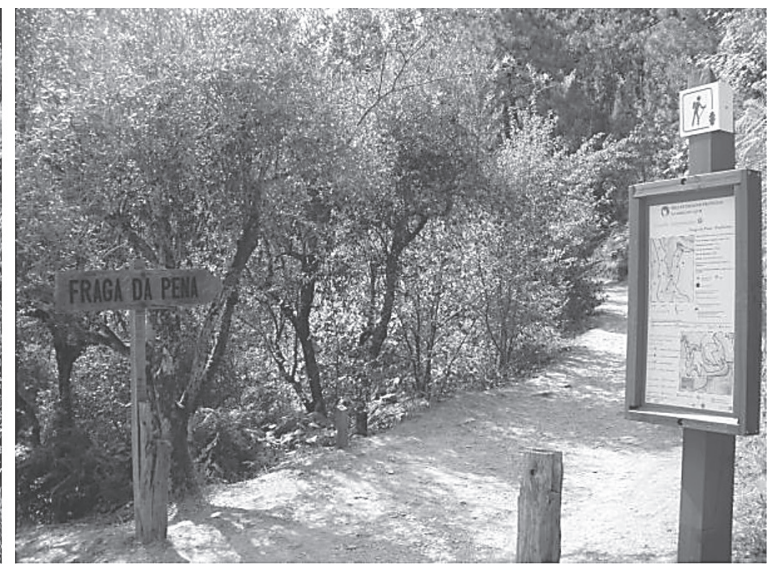

Figuras 28 e 29

Sinalização de Loja Aldeias do Xisto e Turismo Rural (em Aigra Nova/Góis, 2008) e percurso pedestre na Fraga da Pena/Arganil (Área de Paisagem Protegida da Serra do Açor, 2011) 
CARVAlHo, P. (2005) - Património Cultural e Trajetórias de Desenvolvimento em Áreas de Montanha. O exemplo da Serra da Lousã. Dissertação de Doutoramento em Geografia apresentada à Faculdade de Letras da Universidade de Coimbra, Coimbra.

Carvalho, P. (2008) - "Património cultural e estratégias de desenvolvimento em Portugal: balanço e novas perspetivas". In: Arroyo, M. et al. (ed.) - Atas del X Coloquio Internacional de Geocrítica. Barcelona, Universidade de Barcelona, 14 pp. (disponível em: http://www.ub.es/ geocrit/-xcol/289.htm).

Carvalho, P. (2009) - "Planeamento, redes territoriais e novos produtos turísticos ecoculturais". Proceedings 1st Cape Verde Congress of Regional Development. Associação Portuguesa para o Desenvolvimento Regional e Universidade Jean Piaget de Cabo Verde, $19 \mathrm{p}$.

CARVAlHo, P. (2009) - "União Europeia, políticas públicas e desenvolvimento rural". Cadernos de Geografia, Coimbra, Departamento de Geografia e Centro de Estudos de Geografia e Ordenamento do Território (Universidade de Coimbra), n²6/27 (2007/2008), pp. 67-76.

Cavaco, C. (2006) - "Práticas e lugares de turismo". In: FonseCA, M. L. (org.) - Desenvolvimento e Território: Espaços Rurais Pós-agrícolas e Novos Lugares de Turismo e Lazer. Lisboa, Centro de Estudos Geográficos, pp. 299-362.

Cavaco, C. (2009) - "Os espaços rurais como espaços de vida: mobilidades residenciais e novas formas de habitar". In: BATISTA, F. et al. (eds) - Os Territórios de Baixa Densidade em Tempo de Mudança. Proença-a-Nova, CMPA e CCVF, pp. 39-72.

Claval, P. (2007) - "Changing Conceptions of Heritage and Landscape". In: Moore, N. e Whelan, Y. (eds.) - Heritage, Memory and the Politics of Identity. News Perspetives on the Cultural Landscape. Aldershot, Ashgate, pp. 85-94.

Correia, J. e Carvalho, P. (2011) - "Turismo e desenvolvimento rural. O caso do Piódão (Aldeias Históricas de Portugal)". Cadernos de Geografia, Coimbra, Departamento de Geografia e Centro de Estudos de Geografia e Ordenamento do Território (Universidade de Coimbra), n 28/29 (2009/2010), pp. 117-130.

Covas, A. (2011) - "Futuros do mundo rural português: de espaço produtor a espaço produzido: mercadorias emergentes e neo-rurais". In: Figueiredo, E. et al. (coords.) - O Rural Plural - olhar o presente, imaginar o futuro. Coleção Territórios em Mudança. Castro Verde, Editora 100LUZ, pp. $59-70$.

Cristóvão, A., Medeiros, V. e Melides, R. (2011) - "Aldeias Vinhateiras, Aldeias Vivas?". In: Figuelredo, E. et al. (coords.) - O Rural Plural - olhar o presente, imaginar o futuro. Coleção Territórios em Mudança. Castro Verde, Editora 100LUZ, pp. 175-188.
GonÇALVES, R. (2011) - "Reflexões sobre a salvaguarda do património paisagístico". Património Estudos, Lisboa, IGESPAR, $n^{\circ} 11$, pp. 42-47.

HenRIQues, E. B. (2010) - "Itinerários turísticos temáticos e património: questões críticas para um turismo responsável e humanista". In: SAnTos, M. G. (org.) - Turismo Cultural, Territórios e Identidades. Porto, IPL e Edições Afrontamento, pp. 221-234.

HowARD, P. (2003) - Heritage: management, interpretation, identity. London, Continuum, pp. 1-13.

IPPAR (2004) - Revista Estudos/Património. Lisboa, Instituto Português do Património Arquitetónico e Arqueológico, $n^{\circ} 7$ (Outros Patrimónios), pp. 5-55; 221.

Keamey, A. (2009) - "Intangible Heritage. Global awareness and local interest". In: SMiтh, L. e AkAGaWA, N. (eds.) - Intangible Heritage. London and New York, Routledge, pp. 209-225.

MagalHães, I. R. (2011) - "O património e a sua sobrevivência: riscos e prevenção”. Património Estudos, Lisboa, IGESPAR, $n^{\circ} 11$, pp. 48-53.

Martínez Arroyo, F. (2006) - "El desarrollo rural en el contexto de la Unión Europea". Norba (Revista de Geografía), vol. XI, Cáceres, Universidad de Extremadura, pp. 11-20.

Moyano Estrada, E. (2006) - "Nuevas orientaciones de la política europea de desarrollo rural. A propósito del Nuevo Regulamento de Desarrollo Rural”. Atas del VI Coloquio Ibérico de Estudios Rurales. Huelva, Universidade Internacional de Andaluzia, 21 pp. (edição em cd-rom)

MoReno, L. (2007) - Desenvolvimento Territorial - de um sentido ocidental às orientações coesivas para um meio rural inovador. Caminhos e Caminhantes. Lisboa (e-book a partir da dissertação de doutoramento em Geografia apresentada à Universidade de Lisboa, em 2002).

MoReno, L. (2009) - "Empreendedorismo e promoção territorial das áreas rurais". In: BATISTA, F. et al. (eds) - Os Territórios de Baixa Densidade em Tempo de Mudança. Proença-a-Nova, CMPA e CCVF, pp. 121-132.

Pereira, P. (2010) - "Sob o signo de Sísifo. Políticas do património edificado em Portugal, 1980-2010". In: IGESPAR (2010) Portugal 1910-2010. 100 Anos de Património, Memória e Identidade. Lisboa, Instituto de Gestão do Património Arquitetónico e Arqueológico, pp. 261-280.

PIREs, A. (2011) - "Nas Aldeias Históricas. Fronteiras Reais e Imaginadas". In: PIRES, A. (aut.) - Recursos e Território. Uma Geografia da Esperança. Coimbra, Comissão de Coordenação e Desenvolvimento Regional do Centro, pp. 26-39.

Plaza GutiérRez, J. (2006) - "Territorio, geografía rural y políticas públicas. Desarrollo y sustentabilidad en las áreas rurales”. Boletín de la A.G.E., n 41, pp. 69-95.

Puente Fernández, L. (2011) - "El valor patrimonial del paisaje: cultura, medioambiente y democracia". Proceedings of 
6th International Congress for Spatial Planning. Madrid, FUNDICOT, pp. 211-225 (www.ciot/6ciot+atas+at4_5.pdf).

SMITH, L. (2006) - Uses of Heritage. London and New York, Routledge, pp. 11-43.

SHARPLEY, R. (2003) - "Rural Tourism and Sustainability". In: HaLL, D.; Roberts, L. e Mitchell, M. (eds.) (2003) - New Directions in Rural Tourism., Aldershot, Ashgate, pp. 38-53.
SinGH, J. P. (2010) - "Global cultural policies and power". In SINGH, J. P. (ed.) - International Cultural Policies and Power. Palgrave Macmillan, pp. 1-15.

Timothy, D. e Nyaupane, G. (2009) - "Heritage tourism and the less-developed world". In: Timothy, D. e Nyaupane, G. (ed.) - Cultural Heritage and Tourism in the Developing World. London and New York, Routledge, pp. 3-19. 